\title{
A REVIEW OF STREET GRILLED MEAT (SUYA) IN BENIN CITY, NIGERIA: A POTENTIAL PUBLIC HEALTH RISK
}

\author{
Okhuebor Shadrach Osalumhense', Izevbuwa Osazee Ekundayo ${ }^{2}$
}

Address (es):

${ }^{1}$ Faculty of life sciences, Department of Microbiology, University of Benin, P.M.B. 1154, Benin City, Edo State, Nigeria.

${ }^{2}$ Department of Microbiology, Faculty of Natural and Applied Sciences, Igbinedion University Okada, P.M.B. 0006, Edo State, Nig eria.

*Corresponding author: osasokhuebor@yahoo.com

ABSTRACT

$\underline{\text { https://doi.org/10.36547/be.2020.3.3.58-61 }}$

Suya originated in the northern parts of Nigeria is ready to eat grilled skewered meat products prepared in different forms spiced with locally sourced, commonly produced by the Hausas in Northern Nigeria. It has permeated Nigerian society, being affordable for all and available everywhere. It is produced from boneless meat hung on stick and spiced with peanut cake, salt, vegetable oil and other flavourings followed by roasting around a glowing charcoal fire. It's generally made with skewered beef, ram, or chicken. Innards such as kidney, liver, and tripe are also used. Suya are of three main forms namely Tsire, Kilishi, and Balangu, and Tsire is the most commonly preferred. In Benin City, which is located in the southern part of Nigeria, Suya has become a very common street food delicacy scattered most major areas and are sold mostly in the evening time, only very few vendors will sell Suya in the day time. Concerns have been raised in many research regarding the public health risk of consuming suya, part of which is food poisoning, as a result microbial contamination such as Bacillus cereus, Staphylococcus aureus, aflatoxigenic molds, Staphylococcus epidermidis, Proteus vulgaris, Klebseilla pneumoniae, Escherichia coli, Candida spp., Salmonella enteritica and Enterobacter spp. Trace metals such as zinc, lead, manganese, iron, and copper have been observed in suya in concentrations exceeding recommended tolerable upper intake levels which can consequently cause serious long term health issues. This study reviews the potential public health risk of consuming street grilled meat (Suya) in Benin City.

Keywords: Suya, public health, contamination, hygiene, food handling, food poisoning

\section{INTRODUCTION}

Meats are rich sources of essential and beneficial minerals needed for body morphological processes. Eating meat, a good source of proteins and fats, plays a major role in the intake of a number of nutritional and trace elements in human health (Adebiyi et al., 2008). Ready to eat meat products in Nigeria are prepared in different forms, one of which is the grilled skewered meat, spiced with locally sourced, mixed dry ingredients that is prepared and sold on the street. Suya is commonly produced by the Hausas in Northern Nigeria. It is produced from boneless meat hung on stick and spiced with peanut cake, salt, vegetable oil and other flavorings followed by roasting around a glowing charcoal fire. It's generally made with skewered beef, ram, or chicken. Innards such as kidney, liver, and tripe are also used (Eke et al., 2012). suya is classified into three main forms namely Tsire, Kilishi, and Balangu (Igene \&Mohanned, 1981; Ahmadu \&Aduwa, 2015). Among the three forms of suya product, Tsire is the most commonly preferred. Although Suya originated in the northern parts of Nigeria, it has permeated Nigerian society, being affordable for all and available everywhere. It has been called a unifying factor in Nigeria (Ekanem, 1998). Suya has become a Nigerian national dish with different regions claiming the superiority of their recipe and methods of preparation, but similar grilled meat recipes are common in many West African countries (Egbebi \& Seidu, 2011). In Benin City, which is located in the southern part of Nigeria, Suya has become a very common street food delicacy scattered most major areas within Benin City (Ahmadu and Aduwa, 2015). Suya spots in Benin City can be located in almost any place there is a bar or any busy area and the vendors are usually from the Northern part of Nigeria. Suya in Benin City are sold mostly in the evening time, only very few vendors will sell Suya in the day time. Concerns have been raised about the hygienic standards of processing and safety of road side Suya (Obadina et al., 2014). This review is aimed at contributing to knowledge on the potential public health risk of consuming street grilled meat (Suya) in Benin City, raising awareness to spark off public health monitoring on street grilled meat (Suya) in Benin City, Edo state, and consequently in all states in Nigeria where it is sold.

\section{SOCIO-ECONOMIC CHARACTERISTICS OF SUYA}

Suya, production in Nigeria remains largely in the hands of small-scale traditional producers and there is little or no information on the economics of its production, especially in Benin City of Edo State. The work of Iliyasu et al., (2013) was on the economic aspect of suya production, the study was conducted in the northern part of Nigeria, Borno State precisely. It is important to know whether suya production is also profitable in the southern part of Nigeria especially Benin City. A study carried out by Ahmadu and Aduwa, (2015) in Benin City Metropolis which comprises mainly Oredo, Egor and Ikpoba-Okha Local Government Areas (LGAs), showed that all of the suya producers were males from northern Nigeria and mostly illitrates who produced suya majorly.
The producers depended mainly on family labour for their production. Personal savings was the dominant source of finance available to the suya producers for their business. Consequently, majority of the producers had low initial capital investment in the suya production business. From this study suya and was found to be profitable in Benin City compared to Borno State as seen in the study of Iliyasu et al., (2013) owing to the fact that there is low production of suya in Benin City which makes it expensive and hence higher returns compared with the high production of suya at Borno with higher population of Hausas that are involved in the business. According to economic theory, low production of a commodity which entails its shortage in the market will lead to increase in its price and consequently, higher returns, all things being equal (Adegeye and Dittoh, 1985). Ahmadu et al., (2008) in his study highlighted that the costs of meat, charcoal and labour significantly influenced the gross income from suya. The effect of frequent rainfall experience in Benin City during the wet season created unfavourable weather that often disrupted the suya production business. This is because majority of the producers had their production/sale stands in the open space (Ahmadu and Aduwa, 2015).

\section{EFFECT PROCESSING AND PACKAGING METHODS OF SUYA}

There is no standard recipe for the production of the complex mixture of spices and additives which make up the Suya and the spice mix served with it (Akpamu et al., 2011). Ingredients may vary according to personal and regional preferences (Egbebi \& Seidu, 2011), and may include clove, ginger, red pepper, black pepper, table salt, and groundnut cake, as well as food additives such as monosodium glutamate and maggi cube (Akpamu et al., 2011). Packaging maintains the benefits of food processing after the process is completed, enabling food to travel safely for long distances from their point of origin and still be wholesome at the time of consumption (Joshua et al., 2016). Most of the processors of this meat were found in strategic locations and were people who does not have much formal education and as a result still uses traditional methods of handling, processing and packaging the products, which are considered to be unhygienic, unsafe and can result in rapid deterioration of the processed meat if not consumed within a short period of time. The processors have been accustomed to collecting old newspapers from different homes and using same to package Suya meat for their customers, which are considered to be dirty and dusty, also in some homes where chemicals were being used to control insects like cockroaches and mosquitoes, there is tendency of the chemicals being sprayed on the newspapers, which the chemicals when in contact with the meat and being consumed can poised serious health issues. Besides the fact that the use of old newspapers in packaging of Suya meat product does not give a good professional image to the processor, the printed inks on the papers contain pigments, colorants, binders, additives and photo initiators which can be harmful to the health of the consumer (Rokade et al., 2012). Packaging does not only ensure that foods contains and maintains the amount and forms of the required ingredient and nutrients but also improves the sensory quality and colour 
stability. It has been demonstrated that food packaging can retard product deterioration, retain the beneficial effects of processing, extend shelf-life and maintain or increase the quality and safety of food (Marsh \& Bugusu, 2007). Therefore it is important that food packaging materials should possess proper mechanical, thermal and optical properties for foods. In addition anti-microbial and barrier functions against gases, vapour and aroma are also important in food packaging materials (Chin et al., 2015). Suya meats are to be stored between 50 to $600 \mathrm{C}$ to disfavour the growth of microbes (Uzeh \& Akinyemi, 2012). The principal roles of packaging are to protect food products from outside influences and damages, to contain the food, and to provide consumers with ingredient and nutritional information (Coles, 2003). A study by Joshua et al., (2016), shows that processing methods and Packaging materials used in the preparation of Suya for consumption have effects on the quality attributes of the final products.

\section{HYGIENE PRACTICES OF SUYA PRODUCERS}

The contamination of street foods in Nigeria have been attributed to factors such as the unstructured nature of the street food industry, inadequate public health infrastructure, the poor state of environmental health and sanitation, and a lack of enforcement of sanitary regulations (Hassan \& Dimassi, 2014) Understanding the factors implicated in the contamination of street foods as well as the health and socio-economic relevance of street foods in Nigeria is important in providing further clarity on the individual hygiene practice of suya producers (Rahman, $\boldsymbol{e t}$ al., 2012). Qualitative studies utilizing focus groups, surveys, and inspection reports however show that food handlers do not always adopt the safe practices that they report including proper hygiene, and the use of risk reduction tools such as thermometers and hand washing (Clayton \& Griffith, 2004; Chapman et al., 2013; Green \& Selman, 2005). The choice of environment and clothing in which suya is prepared and sold is of concern. Chukuezi, (2010) highlighted that in Nigeria, $24 \%$ of street food vendors prepare food under unhygienic conditions, $48 \%$ handle food with their bare hands, $52 \%$ do not wear hair covering, and $62 \%$ handle money while serving food. It is further reported that $19 \%$ wore jewelry while serving food, $29 \%$ blow into polythene bags meant for serving food, and $43 \%$ did not wear appropriate clothing such as aprons. These facts are well observed in suya handlers in Benin City. The unsanitary conditions in which street food vendors operate, coupled with media reports on foodborne disease outbreaks seem to have created consumer mistrust of street foods (Rheinlander et al., 2008). Improving food safety is therefore predicated on knowledge of personal hygiene, adequately cooked foods, avoidance of cross contamination, safe temperatures for stored foods, and avoidance of serving unsafe foods to consumers (Food Safety and Zoonoses, 2006). Adebiyi et al.,(2008) reported the accumulation of high levels of trace metals concentration like zinc, lead, manganese, iron and copper on suya owing possibly to the water removal from raw meat by fire during the roasting process thereby increasing its dry matter; this could have resulted in the increase in metals per mass of the Suya. Anthropogenic sources are additional reasons. He also pointed out the fact that Suya is commonly prepared and sold along roadsides that are usually very busy thus can be exposed to street dusts due to re-suspension mechanisms. Nigeria is known to be very poor in road maintenance; a situation that may explain the presence of dusts on the roads. Suya is roasted on an iron gauze platform using wood charcoal fires, causing exposure to wood smokes and iron rust. These also serve as sources of metal accumulation by Suya. Vehicular emissions comprise another source of contamination. It has been established that particulate matter from vehicle emissions contain some metals (wear metals) (Trevor, 1981). Like the vehicle emissions, particulates from the breakdown of vehicle brake parts can be another source of trace metals in Suya sold along the roadsides in the study locations (Yeung, 2003; Todd, 2003). Another study by Enabulele and Uraih, (2009), showed that in Benin City, improper handling of the suya before and after preparation and most especially from vectors like flies and hands of the sellers themselves, are responsible for contamination by organisms such as E.coli and Salmonella spp.

\section{RISK SOURCES AND PUBLIC HEALTH IMPLICATIONS}

The contamination of ready-to-eat meat products is a common phenomenon in Nigeria that has been reported by many researchers (Chukwu \& Imodiboh, 2009; Fonkem et al., 2010; Salihu et al., 2010; Iheagwara \& Okonkwo, 2016). Suya is normally sold wrapped in old newspaper, which has been criticized for serving as a possible source of contamination (Apata et al., 2013). Tapeworm (Taenia saginata) from infested beef has been found to survive the temperatures used in preparing Suya and remain viable to infect humans (Mosimabale $\boldsymbol{\&}$ Belino, 1980). Cases of haemolytic anaemia have been described after ingestion of Suya, possibly as a result of adulteration of food additives (Williams, et al., 1988). Edema et al., (2008) who evaluated the microbial hazards associated with processing of suya meat, reported that processing water, meat processing labs, utensils, spices, and raw meat revealed contamination with potential pathogens such as Bacillus cereus, Staphylococcus aureus, Salmonellae species, and aflatoxigenic molds with aerobic mesophilic counts in the order of $105 \mathrm{cfu} / \mathrm{g}$, with the highest value (7.17) observed in the packaging material and the lowest value (1.47) observed in the processing water. Adebiyi et al., (2008) reported the accumulation of trace metals such as zinc, lead, manganese, iron, and copper on suya and the concentrations of these metals exceeded recommended tolerable upper intake levels. This is as a result of exposure the suya to open air in busy areas with high human and vehicular movements. Ingestion metals at high doses can result to long term health conditions such as cancers, high noncarcinogenic risks, hormonal disorders, cardiac diseases, neurological disorders, renal failures, reproductive issues such as infertility, immunological disorders (Ekhator et al., 2017).

E. coli, which are normal flora of the human and animal intestine, have been identified as a leading cause of food borne illness all over the world (Agbeyegbe \& Uraih, 1982; Hussein, 2007). Enabulele \& Uraih, (2009), showed that in Benin City, high levels E. coli 0157: H7 strain was detected in some of the raw meat samples and suya. E. coli 0157:H7 prevalence rate where observed to be higher in suya than raw meat which will still be processed before consumption. The high occurrence of E. coli 0157: H7 in suya and raw meat could be as a result of improper handling of the suya before and after preparation and most especially from vectors like flies and hands of the sellers themselves and also poor sanitary environment in Benin City under which the animals are slaughtered and sold.

In similar study by Inusa \& Said, (2017), Suya samples from Kano metropolis of Kano State, Northern-Nigeria, were found to be contaminated by organisms that pose threat to public health. These include Staphylococcus aureus, Staphylococcus epidermidis, Proteus vulgaris, Klebseilla pneumoniae, Escherichia coli, Candida spp., Salmonella enteritica and Enterobacter spp. The microbial contamination that was detected in the locations for sample collection could be traced to unhygienic processing and low level of sanitation. Odey $\boldsymbol{e t}$ al., (2013) isolated Staphylococcus aureus, Escherichia coli, Streptococcus spp, Salmonella spp, Bacillus spp, Pseudomonas spp and Proteus spp. from selected suya samples on sale at Calabar, Cross River State, Nigeria. Okonko et al., (2013) isolated Bacillus spp, Staphylococcus aureus and Escherichia coli in suya samples from Port Harcourt, Rivers State. Study conducted on suya sold in Ado and Akure, South west Nigeria revealed bacteria, molds, yeast, and fungi (Egbebi \& Seidu, 2011). Osho, (2004) also evaluated the bacteria contamination of suya processed in Abeokuta, south western Nigeria and found up to $103 \mathrm{cfu} / \mathrm{g}$ enterobacteriaceae in $40 \%$ of the 622 samples collected; more than $104 \mathrm{cfu} / \mathrm{g}$ aerobic mesophiles including Staphylococcus aureus in all collected samples. Inyang et al. (2005) also evaluated the bacterial quality of suya sold in Markurdi, northern Nigeria and concluded that fecal coliforms were the main bacterial contaminants, although they occurred within acceptable limit.

\section{CONCLUSION AND RECOMMENDATION}

Suya though a highly nutrient dense ready-to-eat meat product, it could be contaminated at the retail outlets. Consequent upon this, it is recommended that consumers cook their own meat properly before they are consumed and also avoid or indiscriminate eating of meat sold in the open. It is also recommended that the public must be aware of the consequences of selling and purchasing Suya in parks and must be discouraged. However, adequate covering of the Suya at the selling points may minimize its contamination from vehicle exhausts and dusts while, instead of direct heating of the raw meat with charcoal fire, an indirect heating such as using microwave oven should be encouraged to prevent direct contact of the meat with charcoal smokes and iron wire gauzes. Good manufacturing practices, proper packaging and storage are recommended to safeguard the health of consumers.

\section{REFERENCE}

Adebiyi, F.M., Sonibare, J.A., Adedosu, T.A., Daramola, A.A., Omode, P.E., \& Obanijesu, E.O. (2008). Assessment of the Effects of Air Pollution Using Road- 
Side Roasted Meats (Suya) as Indicators. Environmental Bioindicators, 3(3),172179. https://doi.org/10.1080/15555270802429700

Adegeye, A.J. \& Dittoh, J.S. (1985), Essentials of Agricultural Economics. Impact Publishers Nig. Ltd, Ibadan, Nigeria, pp. 13-48. https://doi.org/10.12691/ajrd-2-1-1

Agbeyegbe, J.M. Uraih, N. (1982). The prevalence of E. coli in meat samples in Benin City, Nigeria. Microbios Letters, 20:21-28. https://doi.org/10.3329/agric.v13i2.26654

Ahmadu, J. and Aduwa, M.O.A. (2015). Economic analysis of suya production in Benin City, Edo State, Nigeria. Journal of Agricultural Science and Environment, 15(1):15-24. https://journal.unaab.edu.ng/index.php/JAgSE/article/view/1468 Ahmadu, J., Alufohai, G.O., Erhabor, P.O. Igene, J.O. (2008 a). Profitability of Kilishi Production under traditional and modern technologies in Nigeria. Journal of Sustainable Tropical Agricultural Research, 28:14-21. https://doi.org/10.1186/s13570-019-0140-1

Akpamu, U., Nwaopara, A.O., Izunya, A.M., Oaikhena, G.A., Okhiai, O., Idonije, B.O., and Osifo, U.C. (2011). A comparative study on weight changes in rats fed with diet containing Yaji, Yaji-additives and Yaji-spices. Biology and Medicine, 3(5):6-15. http://dx.doi.org/10.3923/tasr.2019.215.225

Apata, E.S., Kuku, I.A., Apata, O.C., \& Adeyemi, K.O. (2013). Evaluation of suya (tsire)- An intermediate moisture meat product in Ogun State, Nigeria. Journal of Food Research, 2(1), 1-7. https://doi.org/10.5539/jfr.v2n1p87

Chapman, B. J., MacLaurin, T. and Powell, D. (2013). Video observation and data coding methods to assess food-handling practices at food services. Food Protection Trends, 25:981-990. http://www.foodprotection.org/files/foodprotection-trends/May-13-Chapman.pdf

Chin, K.B., Han, S. and Ramachandraiah, K. (2015). Nanotechnology in Meat Processing and Packaging: Potential Application -A Review. Asian-Australasian Journal of Animal Sciences, 28(2):290-302. https://doi.org/10.5713/ajas.14.0607 Chukuezi, C.O. (2010). Food safety and hygienic practices of street food vendors in Owerri, Nigeria. Studies in Sociology of Science, 1(1):50-57. http://www.cscanada.net/index.php/sss/article/view/j.sss.1923018420100101.005 Chukwu, O. and Imodiboh, L.I. (2009). Influence of storage conditions on shelflife of dried beef product (Kilishi). World Journal of Agricultural Sciences, 5(1):34-39.https://doi.org/10.5897/JODA.9000007

Clayton, D., \& Griffith, C. (2004). Observation of food safety practices in catering using notional analysis. British Food Journal, 10:211-227. https://doi.org/10.1108/00070700410528790

Coles, R. (2003). Food packaging technology, London, Blackwell publishing CRC press pp. 1-31. https://doi.org/10.1002/pts.655

Edema, M.O., Osho, A.T. and Diala, C.I. (2008). Evaluation of Microbial Hazards Associated with the Processing of Suya (a grilled meat product). Scientific Research and Essays, 3(12):621626.http://dx.doi.org/10.15739/iripeh.16.003

Egbebi, A.O., \& Seidu, K.T. (2011). Microbiological evaluation of suya (dried smoked meat) sold in Ado and Akure, South West Nigeria. European Journal of Experimental Biology, 1(4):1-5.http://dx.doi.org/10.15739/irjpeh.16.003

Ekanem, E.O. (1998). The street food trade in Africa: Safety and socio environmental issues. Food Control, 9(4):211-215. https://doi.org/10.1080/15428052.2016.1225536

Ekhator, O.C., Udowelle, N.A., Igbiri, S., Asomugha, R.N., Igweze, Z.N. and Orisakwe, O.E. (2017). Safety Evaluation of Potential Toxic Metals Exposure from Street Foods Consumed in Mid-West Nigeria. Journal of Environmental and Public Health Volume, 2:1-8 Article ID 8458057, 8 pages https://doi.org/10.1155/2017/8458057

Eke, M.O., Ariahu, C.C., \& Okonkwo, T.M. (2012). Production and quality evaluation of Dambu- nama- A Nigerian dried meat product. Nigerian Food Journal, 30(2):66-72. https://doi.org/10.1016/S0189-7241(15)30037-0

Enabulele, S.A. and Uraih, N. (2009). Enterohaemorrhagic Escherichia coli 0157:H7 Prevalence in meat and vegetables sold in Benin City, Nigeria. African Journal of Microbiology 3(5): 276-279.http://www.academicjournals.org/ajmr Fonkem, D.N., Tanya, V.N. and Ebangi, A.L. (2010). Effects of Season on the Microbiological Quality of Kilishi, a Traditional Cameroonian Dried Beef Product. Tropicultura,

http://www.tropicultura.org/text/v28n1/10.pdf

Food Safety \& Zoonoses. (2006). Five keys to safer food manual. Geneva, Switzerland: World Health Organization Publications. Retrieved at http://www.who.int

Green, L.R., and Selman, C. (2005). Factors impacting food workers and managers, safe food preparation practice: A qualitative study. Food Protection
Trends, 25:981-990. https://www.rti.org/publication/factors-impacting-foodworkers\%E2\%80\%99-and-managers\%E2\%80\%99-safe-food-preparationpractices

Hassan, H. and Dimassi, H. (2014). Food safety and handling, knowledge and practices of Lebanese university students. Journal of Food Control, 40:127-133. http://dx.doi.org/10.1016/j.foodcont.2013.11.040

Hussein, H.S. (2007). Prevalence and Pathogenicity of Shiga toxinproducing Escherichia coli in beef cattle and their products. Journal of Animal Science, 85:63-72. Doi: 10.2527/jas.2006-421. https://doi.org/10.3389/fmicb.2018.02040 Igene, J.O. and Mohammed, I.D. (1981). Consumer altitude towards Suya an indigenous -Nigeria meat product. Journal of Animal Production Research, 4:23. https://doi.org/10.1289/ehp.7339

Iheagwara, M.C. and Okonkwo, T.M. (2016). Effect of Processing Techniques on the Microbiological Quality of Kilishi - A Traditional Nigerian Dried Beef Product. Journal of Meat Science and Technology, 4(1):11-17. https://doi.org/10.5897/JODA.9000007

Iliyasu, A., Iheanacho, A.C., Mshelia, S.I. (2013). Profitability analysis of three methods of suya production and marketing in Maiduguri Metropolitan Council, Borno State, Nigeria. Nigerian Journal of Basic and Applied Sciences. https://www.ajol.info/index.php/njbas/article/view/87173

Inusa, S. K. and Said, I. S. (2017). Evaluation of the Chemical and Microbiological Properties of Kilishi Sold in Kano Metropolis. Journal of dryland Agriculture, 3(1):59-69. https://doi.org/10.5897/JODA.9000007

Inyang, C.U., Inyor, M.A., and Uma, E.N. (2005). Bacteriological quality of a smoked meat product (suya). Nigerian Food Journal, 23:239-242. https://doi.org/10.4314/nifoj.v23i1.33622

Joshua, O.O., Obafemi I.O., Temiloluwa, C.M. (2016). Effects of processing methods and packaging materials on the quality attributes of Suya meat. Ukrainian Journal of Food Science, 4(2):248-257. https://doi.org/10.24263/23101008- 2016-4-2-7

Marsh, K. and Bugusu, B. (2007). Food packaging- roles, materials and environmental issues. Journal of Food Science, 72:23-36.

https://doi.org/10.1111/j.1750-3841.2007.00301.x

Mosimabale, F.O., \& Belino, E.D. (1980). The recovery of viable Taenia saginata cysticerci in grilled beef, "suya", in Nigeria. International Journal of Zoonoses, 7(2):115-119. https://doi.org/10.1080/15428052.2016.1225536

Nester, E.W., Aderson, D.G., Roberts, C.E., Pearsall, N.N., \& Nester, M.T. (1998). Dynamic of bacterial growth in microbiology. A human perspectives. (2nd, pp. 86-92). New York, NY: McGraw Hill. https://doi.org/10.1080/15428052.2016.1225536

Obadina, A.O., Oyewole, O.B., \& Ajisegiri, O.A. (2014). Identification of hazards and critical control point (CCP) for "suya" processing in South-West Nigeria. Journal of Food Processing and Preservation, 38:2057-2060. https://doi.org/10.1080/15428052.2016.1225536

Odey, M.O., Mboso, E.O., Ujong, U.P., Johnson, J.T., Gauje, B. and Ategwu, M.A. (2013). Microflora Analysis of Selected Meat and Meat Products from Calabar, Cross River State Nigeria. Archives of Applied Science Research, 5(3):50-56. https://doi.org/10.5897/JODA.9000007

Okonko, I.O., Odu, N.N. and Igboh, I.E. (2013). Microbiological Analysis of Kilishi Sold In Port Harcourt, Nigeria. New York Science Journal, 6(7):37-43. https://doi.org/10.11604/pami.2019.33.219.17729

Osho, A.T. (2004). Evaluation of bacterial contamination of grilled meat (Suya) processed in Abeokuta. Undergarduate research project (p. 49). Abeokuta, Nigeria: Department of Nutrition and Dietetics, University of Agriculture. https://academicjournals.org/journal/SRE/article-full-text-pdf/D15144A16486

Rahman, M., Arif, M., Baker, K., and Tambi, Z. (2012). Food safety knowledge, attitudes, and hygiene practices among street food vendors in Northern Kuching City, Sarawak. Borneo 31:95-103. https://scholarworks. waldenu.edu/cgi/viewcontent.cgi?article $=4889 \&$ context=dis sertations

Rheinlander, T., Olsen, M., Bakang, J., Takyi, H., Konradson, F., and Samuelsen, H. (2008). Keeping up appearance: Perceptions of street food safety in urban Kumasi, Ghana. Journal of Urban Health, 85(6):952-964. https://doi.org/10.1007/s11524-008-9318-3

Rokade, M.M., Rokade, P.R., Thakare, S.R., Rupvate, N.B., Mahale, I. and Sanjay, R.C. (2012). Formulation design and evaluation of transdermal film of Losartan Potassium using hydrophilic and hydrophobic polymers. American Journal of Pharm Tech Research, 8:22-28.

Salihu, M.D., Junaidu, A.U., Magaji, A.A., Aliyu, R.M., Yakubu, Y., Shittu A. and Ibrahim, M.A. (2010). Bacteriological Quality of Traditionally Prepared 
Fried Ground Beef (Dambun Nama) in Sokoto, Nigeria. Advance Journal of Food Science and Technology, 2(3):145-147. https://maxwellsci.com/jp/abstract.php?jid=AJFST\&no $=48 \&$ abs $=01$

Todd, J. (2003).Wood-smoke Handbook: Wood heaters, Firewood and Operator Practice Environment, Australia. 31. https://www.cleanairtas.com/links/woodsmoke-handbook.pdf

Trevor, M. (1981). Atomic Absorption spectrophotometry for the analysis of wear metals in oil samples Varian Instruments. AA-10, 1-9. http://www1.lasalle.edu/ prushan/Intrumental\%20Analysis_files/AA-

Perkin\%20Elmer\%20guide\%20to\%20all!.pdf

Uzeh, R.E and Akinyemi, M.O. (2012). Microbiological and physico-chemical characteristics of stored Tsire-Suya, a roasted meat product. International Journal of Biological Chemical Science, 4:1804-1809. https://doi.org/10.4314/ijbcs.v6i4.35

Williams, C.K., Osotimehin, B.O., Ogunmola, G.B., and Awotedu, A.A. (1988). Haemolytic anaemia associated with Nigerian barbecued meat (red suya). African Journal of Medicine and Medical Sciences, 17(2):71-75. https://doi.org/10.1080/15428052.2016.1225536

Yeung, Z.L.L., Kwokb, R.C.W. and Yua, K.N. (2003). Determination of multielement profiles of street dust using energy dispersive X-ray fluorescence (EDXRF). Applied Radiation and Isotopes 58:339-346. https://doi.org/10.1016/s0969-8043(02)00351-2 